2011

\title{
A Survey of Clergy Practices Associated with Premarital Financial Counseling
}

Ryan E. Halley

George Fox University, halleyr@georgefox.edu

Dorothy B. Durband

Texas Tech University

William C. Bailey

University of Arkansas

A. William Gustafson

Texas Tech University

Follow this and additional works at: https://digitalcommons.georgefox.edu/gfsb

Part of the Christianity Commons, and the Finance and Financial Management Commons

\section{Recommended Citation}

Halley, Ryan E.; Durband, Dorothy B.; Bailey, William C.; and Gustafson, A. William, "A Survey of Clergy Practices Associated with Premarital Financial Counseling" (2011). Faculty Publications - School of Business. 111.

https://digitalcommons.georgefox.edu/gfsb/111 


\title{
A Survey of Clergy Practices Associated with Premarital Financial Counseling
}

\author{
Ryan E. Halley, Ph.D. \\ Assoc. Professor of Finance \\ Chair, Undergraduate Department of Business \& Economics \\ George Fox University \\ Newberg, Oregon \\ Dorothy B. Durband, Ph.D. \\ Assoc. Professor of Personal Financial Planning \\ Texas Tech University \\ Lubbock, Texas \\ William C. Bailey, Ph.D. \\ Assoc. Professor of Human \& Family Development \\ University of Arkansas \\ Fayetteville, Arkansas \\ A. William Gustafson, Ph.D. \\ Assoc. Professor of Personal Financial Planning \\ Director, Center for Financial Responsibility \\ Texas Tech University \\ Lubbock, Texas
}

Correspondence may be sent to: Dr. Ryan E. Halley, e-mail halleyr@georgefox.edu

\begin{abstract}
The purpose of this exploratory study was to gain an understanding of the state of clergy-led premarital financial counseling. Clergy respondents $(n=223)$ indicated that they often include a financial component in their formal premarital counseling. The most frequently discussed financial topics are budgeting, managing debt and credit, and saving. The most frequently cited obstacles to providing premarital financial counseling are lack of time and lack of subject matter expertise.
\end{abstract}

Key words: Clergy, Premarital Counseling, Financial Counseling, Financial Education

t has been estimated that between $40 \%$ and $50 \%$ of all first marriages will end in divorce (Bramlett \& Mosher, 2001; Risch, Riley, \& Lawler, 2003; Stanley, 2001). Even though the divorce rate for first marriages seems to be lowering, the long-term fate of more recent marriages is harder to predict. It still appears that a significant percentage of first marriages will result in divorce (Stevenson \& Wolfers, 2007). The social, economic, and political consequences of marital dissolution are vast and practically immeasurable (Licata, 2002).

As much as the ability to manage personal finances successfully within a marriage can strengthen this relationship, financial crises and poor communication about financial issues can be devastating to a marriage. Typically, many factors contribute to marital break-up, and disputes over money issues tend to increase the risk of divorce or lead to serious marital conflict (Dew, 2007; Schramm, Marshall, Harris, \& Lee, 2005; Stanley, 2001). Olson and DeFrain (2000) found that $37 \%$ of all married couples list money issues as the primary point of conflict in their marriage. Other studies support the conclusion that financial problems are the most likely cause for marital conflict (Geiss, 1981). Papp, Cummings, and Goeke-Morey (2009) found that, when compared to nonmonetary issues, "marital conflicts about money were more pervasive, 
problematic, and recurrent, and remained unsolved, despite including more attempts at problem solving" (p. 91).

Because more than $75 \%$ of all marriages take place in religious institutions (Licata, 2002), members of the clergy serve as the primary providers of premarital counseling (Bruhn \& Hill, 2004; Silliman \& Schumm, 1995; Stanley, 2001; Williams, 2007). In fact, Stanley, Amato, Johnson, and Markman (2006) found that couples who are married in a religious setting are seven times more likely to receive premarital education than couples who are married in other settings. Clergy are generally aware that the overwhelming preponderance of premarital counseling takes place under their direction (Jones \& Stahmann, 1994). Sullivan, Pasch, Cornelius, and Cirigliano (2004) found that $88 \%$ of husbands and $94 \%$ of wives in their study reported that their premarital counseling was obtained through a religious institution. The national study of 231 clergy members by Jones and Stahmann (1994), reports that $92 \%$ of their sample serve as the primary providers of premarital counseling. Clergy tend to concentrate on spiritual development, generating a concern that they fail to incorporate other issues such as finance that may lead to areas of conflict for premarital couples (Boisvert et al., 1992).

Although few studies concerning the design and content of religiously-affiliated premarital counseling have been reported, several studies do address the lack of preparation that clergy feel in working with premarital couples. Despite the fact that money is one of the most pressing issues for many couples in marriage, the existing literature is nearly devoid of research describing the attitudes and practices of clergy pertaining to the inclusion of a financial component in formal premarital counseling. Various researchers have supported the notion that clergy as a whole have failed to devote adequate time to this subject (e.g., Buikema, 2001; Risch et al., 2003; Russell \& Lyster, 1992).

Quite possibly, fewer successful, first-time long-term marriages exist today because these couples fail to receive the information and counseling they need to build such marriages (Licata, 2002). Even for such couples that undergo formal premarital counseling, little standardization exists among programs. Additionally, little is known about the beliefs and practices of premarital counseling providers relating to marital longevity and success (Jones \& Stahmann, 1994). Never the less, premarital education has been shown to work, increasing marital satisfaction and lowering conflict. Stanley et al. (2006) found that couples who participated in premarital education were $31 \%$ less likely to have their marriage end in divorce.

This exploratory study was designed to investigate the state of personal finance inclusion in clergy-led premarital counseling within a faith community. Two hundred twenty three Texas clergy were surveyed in an effort to assess the extent of inclusion of personal financial matters within their premarital counseling practices as well as their perception of preparedness for addressing financial topics with couples. This article is a-theological in its nature, and the authors are aware the role of clergy can be defined with much variety. This research is relevant for clergy who do premarital counseling.

Method

Population and Sample

Exploratory research methods were used in this study because almost no previous research has been conducted on the presence of a financial component within formal clergy-led premarital counseling. The seven largest Christian denominations in the U.S. (according to church membership) were chosen as an initial selection criterion because they typically have a formal structure that includes a national headquarters and a seminary or group of seminaries. According to the American Religious Identification Survey (ARIS) and National Survey of Religious Identification (NSRI) website data for 2001, the Christian denominations that met the 
inclusion criteria were: Roman Catholic, Baptist, Methodist, Lutheran, Episcopal, Pentecostal, and Presbyterian (ARIS \& NSRI).

The target population was further narrowed to senior clergy members from the seven denominations in the four largest metropolitan areas in Texas: Austin, Dallas/Fort Worth, Houston, and San Antonio. The initial stage involved using YellowPages.com to select all religious organizations fitting the denomination and location criteria for the sampling frame.

Stratified sampling was used in this study. If the amount of churches from the respective denomination and location was less than 50 , all of the churches of the respective denomination and location were included in the sample. If the amount was greater than 50 , systematic sampling was used to select 50 churches from the respective denomination and location. Lowfrequency denominations were intentionally oversampled to allow for greater diversity of denominations. This procedure resulted in 981 religious institutions.

Once the sample of churches was selected, the researchers attempted to make an initial contact either through the church website or by phone. When the researchers were unable to make contact with a selected church in two phone call attempts, that church was deleted from the sample, and contact with the next church on the list was initiated. This procedure was repeated until contact was made with 50 churches. A survey was sent to a church only if the senior clergy member's name and address of the church were confirmed.

Instrument

Benson and Clark's (1982) instrument development and validation procedure was used as a guide to create the survey instrument. The item pool was composed of questions formulated by the researchers or prompted by a review of existing literature, especially works that highlighted the desire of couples for financial matters in premarital counseling (Boisvert et al., 1992; Knox \& Knox, 1974; Risch et al., 2003; Sullivan \& Anderson, 2002; Williams, 1992; Williams, Riley, Risch, \& Van Dyke, 1999) and literature that documented the lack of preparation that clergy feel in regard to premarital counseling (Buikema, 1999; 2001), although no questions from previous instruments were used.

The instrument went through multiple reviews and revisions. The researchers consulted with a minister who is also a family finance professor with expertise in premarital and marital finances. A panel of experts consisting of six consumer economics and personal financial planning faculty and seven doctoral students initially evaluated the items. Next, a pretest was conducted with a group of 19 ministers not included in the final study. Finally, a pilot test was conducted using a sample of 110 Lubbock, TX ministers representing the denominations included in the final study. Eighteen usable responses were returned by the pilot test sample, representing a $16 \%$ response rate. Respondents were asked to indicate instrument items that were unclear or needed to be reevaluated. Concerns over instrument length (63 questions) were cited in the pretest and again in the pilot study. Questions that were deemed nonessential were eliminated. The respondents from the pilot study were not included in the final sample.

One other modification to the study was made based upon the pilot study results. No responses were received from the Roman Catholic and Pentecostal churches. The researchers reviewed the historic premarital counseling practices of each denomination to look for indications as to why there were no responses from these denominations. Based on a conversation with a Roman Catholic premarital counseling provider in Lubbock, it was determined that premarital counseling in the Roman Catholic Church is typically provided by church lay leaders (e.g., deacons and others). Often, the senior clergy in the church, the priest, is not involved in the premarital counseling function. Ideally, if the Roman Catholic Church were to be included in this study, the individual receiving the survey should be the individual most 
involved in the premarital counseling function; however, this did not match the study's methodology.

The Pentecostal Church was excluded from the final sample due to a telephone conversation with its national headquarters to inquire about premarital counseling practices. A leader at the Church responded that the Pentecostal Church has no stated position on premarital counseling and that most of their clergy are not seminary trained and would not be schooled in premarital counseling. This lack of premarital counseling within the Pentecostal Church likely contributed to the lack of response rate in the Pentecostal Church in the pilot study.

Procedure

A slightly modified version of Dillman's (2000) Tailored Design Method was used. A cover letter introduced the study, provided details for completing the survey, and encouraged the senior clergy to participate. The clergy were asked to complete the 52-item instrument and return it by mail. A thank you postcard was sent one week after the initial mailing.

Two weeks after the postcards were mailed, the sample was sent a final follow-up mailing. This letter emphasized the significance of the study and encouraged participation. The survey was open for six weeks, from April to May, 2005.

In this study, 685 questionnaires were mailed to senior clergy in four Texas cities: Austin, Dallas/Fort Worth, Houston, and San Antonio. Of these, two were returned by the post office as undeliverable. The questionnaires returned were 225 , representing a $32.9 \%$ response rate. Two of the questionnaires were incomplete and could not be used, reducing the total usable number of responses to $223(32.7 \%)$.

Data were screened using frequencies, crosstabs, and scatter plots in SPSS to identify errors in data entry and out-of-range responses. No problems were found in the data. Descriptive statistics such as frequencies, percentages, means, and ranges were used to answer the research questions.

Research Questions

Five research questions are addressed in this study: (1) how frequently are financial topics covered in formal clergy-led premarital counseling? (2) what financial topics are clergy discussing within formal premarital counseling? (3) if a financial component is not being covered in formal clergy-led premarital counseling, why are clergy not talking about financial issues? (4) what preparation do clergy have to include financial issues within formal premarital counseling? (5) how well do clergy feel that their educational background has prepared them for dealing with financial issues within formal premarital counseling?

Results

Due to the exploratory nature of this initial study involving senior clergy, the research team deemed it important to record the response rates by denomination and location. Table 1 provides a summary of return rates by denomination and Table 2 summarizes response rates by location.

Approximately one-fourth $(24.9 \%)$ of the respondents were leaders of churches with membership of 500 to 999 individuals, while another $22.2 \%$ were from churches with membership between 300 and 499 . The third most represented category was churches with 1,000 to 3,000 members (15.8\%), and $12.2 \%$ of the respondents were from 100 to 199 member churches. Clergy from the largest churches in this study (more than 3,000 members) returned $8.1 \%$ of all responses and those from churches of 200 to 299 members returned $7.7 \%$ of the questionnaires. Smaller churches were least represented, as $6.8 \%$ of the senior clergy who 
returned a survey led churches with 50 to 99 members and $2.3 \%$ of the respondents led churches with less than 50 members.

Table 1. Response Rates by Denomination

\begin{tabular}{llll} 
& $\begin{array}{l}\text { Target Sample } \\
\text { Size }\end{array}$ & $\begin{array}{l}\text { Responses } \\
\text { Received }\end{array}$ & $\begin{array}{l}\text { Response } \\
\text { Rate }\end{array}$ \\
\hline Baptist & $198^{\star}$ & 53 & $26.8 \%$ \\
Methodist & 177 & 50 & $28.2 \%$ \\
Lutheran & 136 & 59 & $43.4 \%$ \\
Episcopal & 76 & 24 & $31.6 \%$ \\
Presbyterian & 96 & 35 & $36.5 \%$ \\
Unidentified & N/A & 2 & N/A \\
Total & 683 & 223 & $32.7 \%$ \\
\hline
\end{tabular}

* Includes 2 undeliverable mailings

Table 2. Response Rates by Location

\begin{tabular}{llll} 
& $\begin{array}{l}\text { Target Sample } \\
\text { Size }\end{array}$ & $\begin{array}{l}\text { Responses } \\
\text { Received }\end{array}$ & $\begin{array}{l}\text { Response } \\
\text { Rate }\end{array}$ \\
\hline Austin & 137 & 52 & $38.0 \%$ \\
Dallas/Fort Worth & $187^{*}$ & 51 & $27.3 \%$ \\
Houston & 196 & 62 & $31.6 \%$ \\
San Antonio & $163^{*}$ & 57 & $35.0 \%$ \\
Unidentified & $\mathrm{N} / \mathrm{A}$ & 1 & $\mathrm{~N} / \mathrm{A}$ \\
Total & 683 & 223 & $32.7 \%$ \\
\hline
\end{tabular}

* Two undeliverable mailings were from Dallas/Fort Worth and San Antonio

The majority of the respondents $(90.6 \%)$ reported that their church requires premarital counseling of all couples getting married in their institution. Almost all participants who responded $(96.0 \%)$ perform some of the premarital counseling taking place within their respective churches, while almost half $(49.8 \%)$ conduct $100 \%$ of the premarital counseling and $83.7 \%$ of the sample conducted over $50 \%$ of all premarital counseling within the church. Only nine of the 223 respondents reported no involvement in premarital counseling.

The first research question asked how frequently were financial topics covered in formal clergy-led premarital counseling. The responses $(n=223)$ to this question were on a 5-point Likert-type scale from 1 (Never) to (Very Often). As shown in Table 3, only two of the clergy respondents reported that they never discussed personal financial issues in premarital counseling, while $82.2 \%$ of the respondents reported that they discussed finances within premarital counseling either often or very often.

A follow-up question was asked to ascertain how much time clergy devote to financial matters within premarital counseling. Limiting this section to only asking the frequency of discussion would miss the depth and the extent of financial coverage. The responses ranged from no time spent discussing financial matters to six hours devoted to personal finances. The average amount of time that participants reported as being devoted to the discussion of financial issues in premarital counseling was 1.2 hours $(S D=.95)$. Table 3 includes a distribution of clergy responses. 
Table 3. Discussion of Finances in Premarital Counseling $n^{\text {a }}$ $\%^{\mathrm{b}}$

\begin{tabular}{|c|c|c|}
\hline Frequency of financial & $n=$ & \\
\hline Never & 2 & 0.9 \\
\hline Seldom & 9 & 4.2 \\
\hline Sometimes & 27 & 12.7 \\
\hline Often & 70 & 32.9 \\
\hline Very Often & 105 & 49.3 \\
\hline Time spent on financial & $n=$ & \\
\hline 15 minutes or less & 16 & 7.9 \\
\hline $16 \mathrm{~min}$. to $30 \mathrm{~min}$. & 40 & 19.8 \\
\hline $31 \mathrm{~min}$. to $45 \mathrm{~min}$. & 15 & 7.4 \\
\hline $46 \mathrm{~min}$. to 1 hour & 56 & 27.7 \\
\hline $1.1 \mathrm{hrs}$. to $1.5 \mathrm{hrs}$. & 33 & 16.3 \\
\hline $1.6 \mathrm{hrs}$. to $2 \mathrm{hrs}$. & 27 & 13.4 \\
\hline $2.1 \mathrm{hrs}$. to $5 \mathrm{hrs}$. & 12 & 5.9 \\
\hline More than $5 \mathrm{hrs}$. & 3 & 1.5 \\
\hline
\end{tabular}

The second research question was what financial topics are clergy discussing within formal premarital counseling? Table 4 presents a summary of the responses. Budgeting was the most frequently cited financial topic that is discussed in premarital counseling, listed by $59.5 \%$ of the respondents. Managing debt and credit was the second most frequent $(48.7 \%)$, followed by saving $(36.4 \%)$, spending $(25.1 \%)$, discussing goals and financial plans $(20.5 \%)$, who will manage the finances within the marriage $(20.5 \%)$, and charitable giving and tithing $(20.0 \%)$. All other responses were listed by less than $20 \%$ of the sample.

Most clergy did not address the open-ended part of the question that inquired about the amount of time spent on specific financial topics. Those clergy who did respond to this portion of the question typically provided an allocation of hours spent on the discussion of finances in general rather than on specific topics.

A second approach to answer this research question was to ask clergy how frequently they discussed five common areas of conflict (debt, lifestyle, separate vs. joint accounts, spending vs. saving, and one income vs. two income families) pertaining to personal finances within marriage. As shown in Table 5, overall, clergy reported that they often discuss each of these topics within their premarital counseling.

The third research question was if a financial component is not being covered in formal clergy-led premarital counseling, why are clergy not talking about financial issues? Out of the sample of 223, there were only 14 clergy responses that addressed this question. It is assumed that the remainder of the clergy members who returned a completed survey did not answer this question because they include finances to some extent within their premarital counseling. The three major themes that emerged from analyzing the 14 responses were that clergy members felt they did not have enough time, that they did not feel adequately prepared in finances, and 
that they choose to devote their premarital counseling time to issues in which they feel more competent (five indicating each of these reasons). Other reasons listed were that finances were not an obvious need for couples and that there are limited good resources at clergy disposal.

Table 4. Financial Topics Discussed

\begin{tabular}{|c|c|c|}
\hline & $n^{a}$ & $\%^{\mathrm{b}}$ \\
\hline & $n=$ & \\
\hline Budgeting & 116 & 59.5 \\
\hline Managing debt / Credit & 95 & 48.7 \\
\hline Saving & 71 & 36.4 \\
\hline Spending & 49 & 25.1 \\
\hline Goals / Planning & 40 & 20.5 \\
\hline Who will manage the money & 40 & 20.5 \\
\hline Giving / Tithing & 39 & 20.0 \\
\hline Employment / Income & 31 & 15.9 \\
\hline Communicating about money / Working together & 23 & 11.8 \\
\hline How financial decisions will be made & 20 & 10.3 \\
\hline Joint accounts / "his" and/or "her" money & 20 & 10.3 \\
\hline Responsibility / Stewardship & 17 & 8.7 \\
\hline Values / Priorities & 15 & 7.7 \\
\hline Investing & & 7.2 \\
\hline Life / Health / Disability insurance & 13 & 6.7 \\
\hline Wills & 12 & 6.2 \\
\hline Checking account / Organization & 10 & 5.1 \\
\hline Retirement & 10 & 5.1 \\
\hline Children and money (impact, allocation to children) & 8 & 4.1 \\
\hline Lifestyle & 8 & 4.1 \\
\hline Attitudes about money & 7 & 3.6 \\
\hline Spirituality of finances & 7 & 3.6 \\
\hline Financial background / Family of origin issues & 6 & 3.1 \\
\hline Wedding expenses & 5 & 2.6 \\
\hline
\end{tabular}

${ }^{a}$ The $\mathrm{n}$ for categories does not equal 223 because respondents were asked to include more than one answer for this question.

${ }^{b}$ Percentage of respondents indicating this topic is included as part of premarital counseling. Categories do not add to 100 due to respondents being able to list more than one topic.

The fourth research question was what preparation do clergy have to include financial issues within formal premarital counseling? To answer this question, three survey questions inquired about courses that clergy had taken on the topic of personal finances and whether or not they attended seminary. The question about seminary attendance was asked because seminary is one educational common experience that many clergy share.

The first question asked was "have you ever taken an educational course entirely devoted to personal finance topics?" This question was followed by "have you ever taken an educational course that contained a unit or section devoted to personal finance topics?" 
Regarding the first question $(n=222), 131$ respondents $(59.0 \%)$ said they had not taken a course entirely devoted to personal finances, while 91 clergy $(41.0 \%)$ said they had taken such a course as part of their educational background. Of the responses to the second question pertaining to taking a unit or section on personal finance topics $(n=172), 71$ clergy members $(41.3 \%)$ said they had not taken a unit or course in personal finances, while $101(58.7 \%)$ said they had taken part in such material. Of the 223 usable responses, $153(68.6 \%)$ clergy members reported that they had taken either a course or a unit or section within a course devoted to personal finance topics, while 70 clergy members $(31.4 \%)$ indicated that they had neither taken an entire class nor a unit or section devoted to personal finance topics.

As referenced above, the survey instrument inquired about respondents' seminary education. Of the participants $(n=220), 214(97.3 \%)$ reported receiving seminary training.

The final research question asked to what extent the respondent seminary education has prepared them for addressing personal finance matters in premarital counseling. Clergy were asked to respond to a series of four questions that inquired about perceived preparation based on education. Each of these questions was scored on a 5-point Likert-type scale from 1 (Not well at all) to 5 (Extremely well).

The average response of $2.77(S D=1.07)$, indicated that, as a whole, the respondents felt that their educational background prepared them a little less than "fair" for dealing with financial issues within formal premarital counseling. After collapsing categories, approximately $44 \%$ of the sample reported that their educational background prepared them either "not well" or "not well at all" for working with financial issues in premarital counseling. A little less than $26 \%$ of the sample indicated that their educational background prepared them either "well" or "extremely well."

The second and third questions addressed the level of preparation that clergy experienced after taking either an entire course on personal finances or a unit or section of a course devoted to personal finances. Of those that had taken a course entirely devoted to personal finances and responded to this question $(n=89)$, the average score was $3.90(S D=.74)$. Clergy who had taken a course that contained a unit or section devoted to personal finance topics and responded to this third question $(n=100)$, reported an average score of $3.51(S D=.77)$. Although the respondents who had taken a course devoted entirely to personal finances perceived this course as better preparing them for discussing financial topics in premarital counseling as compared to those who had experienced only a unit or section on personal finances, both groups regarded the exposure to personal finance topics within an educational course had a slightly positive impact on their preparation in working with premarital couples.

The final question asked clergy, "how well do you feel that your education at seminary prepared you for addressing financial issues in premarital counseling?" Of the 211 respondents to this question, the average Likert scale score of $2.30(S D=.83)$ revealed that these clergy respondents thought that their seminary education had not prepared them well for addressing financial issues in premarital counseling. After collapsing categories, $67.3 \%$ of the sample thought that their seminary education did either "not well" or "not well at all" prepare them for addressing financial issues in the course of premarital counseling. Only one participant responded that his or her seminary education did provide "extremely well" preparation for addressing financial issues and only $9.5 \%$ indicated "well." A summary of the educational preparation questions and the responses can be found in Table 6.

Discussion

The exploratory nature of this study led to the research decision to cover a diverse group of clergy and churches within the confines of the locations and denominations set forth. This goal was accomplished only to an extent. Even though the background characteristics allow the 
researchers and readers to formulate a picture of the "average" respondent, the sample included clergy members of various socio-demographic characteristics. Although there was some representation from African American, Hispanic and Asian clergy, it was hoped that more ethnic groups would have been represented. The background characteristics of this sample of clergy are considered to be fairly characteristic of many of the most represented church leaders, with ethnicity comprising the one possible exception, which would be highly dependent upon the location of sampling.

Table 5. Frequency of Discussion on Selected Topics

\begin{tabular}{|c|c|c|}
\hline & $\mathrm{n}^{\mathrm{a}}$ & $\%^{\mathfrak{b}}$ \\
\hline Debt & $n=$ & \\
\hline Never & 3 & 1.4 \\
\hline Seldom & 14 & 6.7 \\
\hline Sometimes & 41 & 19.5 \\
\hline Often & 68 & 32.4 \\
\hline Very Often & 84 & 40.0 \\
\hline Lifestyle & $n=$ & \\
\hline Never & 1 & 0.5 \\
\hline Seldom & 13 & 6.2 \\
\hline Sometimes & 39 & 18.6 \\
\hline Often & 82 & 39.0 \\
\hline Very Often & 75 & 35.7 \\
\hline Separate vs. Joint accounts & $n=$ & \\
\hline Never & 7 & 3.3 \\
\hline Seldom & 16 & 7.6 \\
\hline Sometimes & 36 & 17.1 \\
\hline Often & 71 & 33.8 \\
\hline Very Often & 80 & 38.1 \\
\hline Spending vs. Saving & $n=$ & \\
\hline Never & 2 & 1.0 \\
\hline Seldom & 11 & 5.2 \\
\hline Sometimes & 16 & 7.6 \\
\hline Often & 90 & 42.9 \\
\hline Very Often & 91 & 43.3 \\
\hline One income vs. Two income & $n=$ & \\
\hline Never & 2 & 1.0 \\
\hline Seldom & 15 & 7.1 \\
\hline Sometimes & 43 & 20.5 \\
\hline Often & 76 & 36.2 \\
\hline Very Often & 74 & 35.2 \\
\hline
\end{tabular}

${ }^{a}$ The ns for categories do not equal 223 because some respondents inadvertently or intentionally did not answer some questions.

${ }^{b}$ Some categories do not add to 100 due to rounding. 
Table 6. Educational Preparation

\begin{tabular}{lll} 
& $\mathrm{n}^{\mathrm{a}}$ & $\%^{\mathrm{b}}$ \\
\hline $\begin{array}{l}\text { How well do you feel that your educational background } \\
\text { prepared you for dealing with financial issues in premarital } \\
\text { counseling? }\end{array}$ & $n$ & \\
& 218 & \\
Not well at all & 23 & 10.6 \\
Not well & 73 & 33.5 \\
Fair & 66 & 30.3 \\
Well & 43 & 19.7 \\
Extremely well & 13 & 6.0 \\
How well do you feel that your education at seminary & $n$ & \\
prepared you addressing financial issues in premarital & & \\
counseling? & 211 & 13.3 \\
Not well at all & & 54.0 \\
Not well & 28 & 22.7 \\
Fair & 114 \\
Well & 48 \\
Extremely well & 20 \\
${ }^{2}$ The ns for categories do not equal 223 because some respondents inadvertently or \\
intentionally did not answer some questions.
\end{tabular}

The implications of this research affect at least three different parties: researchers, clergy members, and seminaries. Although substantial data is available demonstrating the critical and decisive role finances play in a marriage, suggesting the need for couples to talk about personal finances before marriage, very little effort has been expended in this area. The results and methodology of this study provide a methodological foundation for other researchers to use in pursuing greater clarity about the role that clergy and the Church might play in equipping couples for a successful life-long marriage. Clergy have long been interested in and concerned about the marriages of their congregations' members. They frequently devote significant time and effort to premarital preparation in the form of premarital counseling. Previous studies demonstrate awareness that financial issues present a considerable stressor in many marriages and are the presenting problem in many marriage dissolutions (Dew, 2007; Geiss, 1981; GoekeMorey, 2009; Olson and DeFrain, 2000; Schramm, Marshall, Harris, \& Lee, 2005; Stanley, 2001). It is vital that premarital counseling efforts begin to include and place a heavier emphasis upon discussions of personal finance within the context of marriage. Issues such as budgeting, living within one's means, responsibility with credit, money histories and personalities, role allocations, and how decisions regarding finances will be made are important premarital topics. The topics contained in Table 4 could be a valuable resource for premarital counseling providers who want to consider more financial inclusion in their premarital counseling.

Although not a component of this study, the investigators suggest that the goal of incorporating financial issues in premarital counseling means that clergy need not become experts in personal finances. Possibly, an ideal method for handling premarital financial issues may involve someone with more expertise in financial management. Many potential areas for 
conflict pertaining to personal finances surround attitudes, emotions and personal histories. Professionals trained in therapeutic counseling methods with a background in family systems theory may be most productive. However, it is hoped that this research will provide an impetus for renewed interest in discussing personal finances within clergy-led premarital counseling. Clergy members would benefit by becoming comfortable and sufficiently knowledgeable about financial concerns in order to introduce these issues in premarital counseling or delegate this function to another capable person.

This research also suggests implications for seminaries and other places of clergy training. As seminaries prepare individuals for ministry, their goal is to educate individuals and provide them with the experience in areas that make them successful in their role. Premarital counseling is a very important aspect of a clergy member's role regardless of the number of couples that a clergy member works with each year, as the vital information shared in premarital counseling can work to create stronger marriages and families.

As seminaries develop curricula and degree plans for their students, this research may provide the impetus to consider the amount of emphasis placed on both premarital counseling in general as well as on a personal finance course in particular. This one dimension has the potential to make a rather significant difference in the life of a new clergy. This study should provide the foundation for future studies involving seminaries and their effectiveness in preparing clergy for working with couples in premarital counseling and marriage counseling.

Limitations

There are a few limitations involved with the methodology and findings of this study. As the results were self-reported, a possible limitation of this study is that the accuracy of the results was dependent upon clergy willingness and ability to follow the written instruction and to complete the tasks associated with the instrument. Secondly, if the churches selected do not require premarital counseling for engaged couples, the potential impact of implementing a financial component may be limited due to the minimal premarital counseling opportunities. The final instrument was modified slightly based on the results of the pilot study, despite the low $16 \%$ response rate.

A further limitation of this research is that the generalizability of the findings is limited to the denominations represented in the study and the metropolitan areas that are surveyed. The lack of responses from Catholic clergy, given the long and rich tradition of premarital counseling within the Catholic Church, as well as non-Christian religious leaders has not been addressed or studied is an additional limitation. Lastly, some of the questions in the survey instrument are sensitive in nature and the feedback received from the respondents is self-reported. For some of the items, the respondents' answers could reflect poorly on the premarital counseling services offered at their local church, may indicate deficiencies at their places of education, and may negatively portray the individual's effectiveness to deliver an important ministry of the church. Due to the sensitive nature of some questions, some respondents may have hesitated to indicate their actual feelings or attitudes toward the questions and may have responded with a more socially desirable response. This feature could have positively biased the results. Questions could also have been misinterpreted due to the self-reporting nature of the instrument.

Conclusions

Approximately $65 \%$ of the responding clergy reported conducting over $90 \%$ of all churchsponsored premarital counseling. This finding is important as it indicates that any effort to alter the content or delivery of premarital counseling should initially concentrate on clergy. There are certainly other premarital preparation methods that work for churches, most notably, using 
additional church staff or outsourcing all or some premarital counseling to local licensed counselors or therapists, but the most widely used method involves senior clergy members leading individuals in their congregation through the premarital counseling process (Barlow, 1999; Buikema, 2001; Schumm \& Denton, 1979; Stahmann, 2000; Williams, 1992). The most likely source for premarital counseling remains the Church and its leaders.

There are some important conclusions that were derived from this study. Clergy are interested in the premarital counseling function of their pastoral care role and are particularly interested in implementing a financial component within their premarital counseling. This interest is evidenced by the positive feedback received from respondents and the overall degree of detail on returned surveys.

Clergy respondents did not report that their educational background had prepared them sufficiently for addressing financial issues within formal premarital counseling. Many clergy were interested in receiving easy-to-use financial materials to use with couples in premarital counseling. Due to the fact that respondents confirmed that money is the biggest stressor they see in marriages and the self-reported lack of preparation for covering financial topics in premarital counseling, a strong justification could be made for a collaborative or referral-based model.

Clergy have long been interested in the marriages within their congregations and have devoted significant time and effort into premarital preparation in the form of traditional premarital counseling. As indicated by Papp et al., 2009, "when coaching couples through money-related decisions, areas that cause disagreements or conflicts for couples may require additional time, empathy, and guidance" (p. 102). Although a large proportion of the clergy sample did not consider themselves adequately prepared to engage in discussions about money, many of the participants ranked themselves as stronger in relational skills, empathy and the ability to provide guidance. Whether offering the financial education themselves or using a more collaborative model, clergy are well positioned to help premarital couples build a successful foundation by including a discussion of the financial components of marriage.

\section{References}

ARIS \& NSRI. (n.d.). Largest denominations/denominational families in U.S. Retrieved November 11, 2004, from http://www.adherents.com/rel_USA.html\#families.

Barlow, J. L. (1999). A new model for premarital counseling within the church. Pastoral Psychology, 48(1), 3-9.

Benson, J., \& Clark, F. (1982). A guide for instrument development and validation. The American Journal of Occupational Therapy, 36(12), 789-800.

Boisvert, J., Ladouceur, R., Beaudry, M., Freeston, M. H., Turgeon, L., Tardif, C., Roussy, A., \& Loranger, M. (1992). Perception of marital problems and of their prevention by Quebec young adults. The Journal of Genetic Psychology, 156, 33-44.

Bramlett, M. D., \& Mosher, W. D. (2001). First marriage dissolution, divorce, and remarriage: United States. (Advance data from Vital and Health Statistics; No. 323). Hyattsville, MD: National Center for Health Statistics.

Bruhn, M. D., \& Hill, R. (2004, October). Designing a premarital counseling program. The Family Journal: Counseling and Therapy for Couples and Families, 12(4), 389-391.

Buikema, J. K. (2001). The preparation of pastors in premarital counseling (Doctoral dissertation, lowa State University, 2001). Dissertation Abstracts International, 62, 5365. 
Buikema, J. K. (1999). Pastors and premarital counseling: A descriptive study of Covenant Theological Seminary graduates from 1975-1995. Unpublished doctoral dissertation, Covenant Theological Seminary.

Dew, J. (2007). Two sides of the same coin? The differing roles of assets and consumer debt in marriage. Journal of Family and Economic Issues, 28(1), 89-104.

Dillman, D. A. (2000). Mail and internet surveys: The tailored design method ( $2^{\text {nd }}$ ed.). New York: John Wiley \& Sons.

Geiss, S. K. (1981). Therapist ratings of frequency and severity of marital problems. Journal of Marital and Family Living, 7, 515-520.

Jones, E. F., \& Stahmann, R. F. (1994). Clergy beliefs, preparation, and practice in premarital counseling. The Journal of Pastoral Care, 48, 181-186.

Knox, D., \& Knox, F. (1974). Preparation for marriage: Beyond the classroom. Journal of Family Counseling, 2, 16-22.

Licata, N. (2002, October). Should premarital counseling be mandatory as a requisite to obtaining a marriage license? Family Court Review, 40(4), 518-532.

Olson, D. H., \& DeFrain, J. (2000). Marriage and the family: Diversity and strengths $\left(3^{\text {rd }}\right.$ ed.). Mountain View, CA: Mayfield Publishing.

Papp, L. M., Cummings, E. M., \& Goeke-Morey, M. C. (2009). For richer, for poorer: Money as a topic of marital conflict in the home. Family Relations, 58(1), 91-103.

Risch, G. S., Riley, L. A., \& Lawler, M. G. (2003). Problematic issues in the early years of marriage: Content for premarital education. Journal of Psychology and Theology, 31(3), 253-269.

Russell, M. N., \& Lyster, R. F. (1992). Marriage preparation: Factors associated with consumer satisfaction. Family Relations, 41(4), 446-451.

Schramm, D. G., Marshall, J. P., Harris, V. W., \& Lee, T. R. (2005). After “I do": The newlywed transition. Marriage and Family Review, 38(1), 45-67.

Schumm, W. R., \& Denton, W. (1979). Trends in premarital counseling. Journal of Marital and Family Therapy, 5(4), 23-32.

Silliman, B., \& Schumm, W. R. (1995, Spring). Client interests in premarital counseling: A further analysis. Journal of Sex \& Marital Therapy, 21(1), 43-56.

Stahmann, R. F. (2000, February). Premarital counseling: A focus for family therapy. Journal of Family Therapy, 22(1), 104-116.

Stanley, S. M. (2001). Making a case for premarital education. Family Relations, 50(3), 272-280.

Stanley, S. M., Amato, P. R., Johnson, C. A., \& Markman, H. J. (2006). Premarital education, marital quality, and marital stability: Findings from a large, random household survey. Journal of Family Psychology, 20(1), 117-126.

Stevenson, B., \& Wolfers, J. (2007). Marriage and divorce: Changes and their driving forces. Journal of Economic Perspectives, 21(2), 27-52.

Sullivan, K. T., \& Anderson, C. (2002, October). Recruitment of engaged couples for premarital counseling: An empirical examination of the importance of program characteristics and topics to potential participants. The Family Journal: Counseling and Therapy for Couples and Families, 10(4), 388-397.

Sullivan, K. T., Pasch, L. A., Cornelius, T., \& Cirigliano, E. (2004). Predicting participation in premarital prevention programs: The health belief model and social norms. Family Process, 43(2), 175-193.

Williams, L. (2007). Premarital counseling. Journal of Couple \& Relationship Therapy, 6(1/2), 207-217. 
Williams, L. M. (1992, December). Premarital counseling: A needs assessment among engaged individuals. Contemporary Family Therapy, 14(6), 505-518.

Williams, L. M., Riley, L. A., Risch, G. S., \& Van Dyke, D. T. (1999). An empirical approach to designing marriage preparation programs. The American Journal of Family Therapy, 27(3), 271-283. 